\title{
ANALISIS WACANA TENTANG KEBATHINAN JAWA DALAM NOVEL ANATOMI RASA KARYA AYU UTAMI
}

\author{
Cut Dalillah Sofa ${ }^{1}$, Lucy Pujasari Supratman ${ }^{2}$ \\ ${ }^{1}$ Universitas Telkom, cutdalillah@gmail.com \\ ${ }^{2}$ Universitas Telkom, doktorlucysupratman@gmail.com
}

\begin{abstract}
ABSTRAK
Salah satu penulis yang memiliki pola pikir yang kritis di Indonesia adalah Justina Ayu Utami atau yang lebih dikenal dengan nama pena Ayu Utami. Penulis dari novel terbarunya Anatomi Rasa (2019) ini telah membuktikan eksistensinya di dunia tulis menulis. Dalam novel Anatomi Rasa yang mengangkat tentang kebathinan Jawa atau yang dikenal dengan Kejawen. Permasalahan yang diangkat dalam penelitian ini adlaah mengenai bagaimana pesan yang ingin disampaikan oleh Ayu sebagai penulis kepada pembaca, dimana Kebathinan Jawa sendiri memiliki makna yang bias atau luas. Hasil penelitian menunjukkan Kebathinan Jaw ayang disampaikan oleh Ayu adalah bagaiamna cara mengolah rasa sehingga seseorang dapat lebih mendekatkan diri kepada sang pencipta dan bermeditasi untuk menanggulangi atas segala hal yang kurang baik dalam kehidupan. Selain itu, Ayu juga menjelaskan tahap - tahap dalam bermeditasi dan fungsi dari tiap tahap tersebut.
\end{abstract}

Kata Kunci : Analisis Wacana Laclau dan Mouffe, Kebathinan Jawa, konstruktivis

\section{ABSTRACT}

One of the writers who has a critical mindset in Indonesia is Justina Ayu Utami or better known by the pen name Ayu Utami. The author of his latest novel Anatomi Rasa (2019) has proven its existence in the world of writing. In the novel Anatomy Rasa which raised Javanese kebathinan or known as Kejawen. The problem raised in this study is how the message Ayu wants to convey to the reader, where Javanese Kebathinan itself has a biased or broad meaning. The results of the research showed that Javanese kebathinan who was conveyed by Ayu as a way of processing the taste so that one can get closer to the creator and meditate to overcome all things that are not good in life. In addition, Ayu also explained the stages in meditation and the functions of each stage.

Keywords: Analysis of Laclau and Mouffe Discourse, Javanese Kebathinan, constructivist

ISSN: 2355-0287, E-ISSN: 2549-3299

http://ejournal.bsi.ac.id/ejurnal/index.php/jika 


\section{PENDAHULUAN}

Indonesia sendiri memiliki banyak penulis dengan beragam gagasan yang dimiliki, yaitu: Pramoedya Ananta Toer, Sapardi Djoko Darmono, A. Fuadi, Ayu Utami dan banyak lainnya. Satu penulis yang sering menuangkan gagasan kritisnya dengan banyak genre tabu di Indonesia seperti spiritual, politik dan isu isu nasional, dengan nama asli Justina Ayu Utami dikenal dengan nama pena Ayu Utami.

Dari beragam karya yang ditulis oleh Ayu, novel Anatomi Rasa menjadi buku paling menarik untuk diulik, dalam pemahamannya untuk dapat memahami pembeda fiksi terbagi menjadi beberapa jenis, yaitu : cerita pendek, roman, novel populer, novel Teenlit, dan novel serius. Dalam pengertiannya dapat dipahami bahwasannya novel serius biasanya mengambil realitas kehidupan ini sebagai model, kemudian menciptakan sebuah "dunia baru" lewat pengembangan cerita dan penampilan tokoh - tokoh dalam situasi yang khusus. Novel jenis ini pun terangnya tidak dibaca sekali saja namun dapat berulang kali untuk memahami makna dan isi dari novel serius tersebut, ini dimaksudkan untuk menghindari kesalahan pemaknaan. Novel serius biasanya berusaha mengungkapkan sesuatu yang baru dengan cara pengucapan yang baru pula. Singkatnya: unsur kebaruan diutamakan. Tentang bagaimana suatu bahan (baca: gagasan, ide, tema) diolah (baca: diungkapkan) dengan cara yang khas, adalah hal yang penting dalam teks kesastraan (Nurgiyantoro, 2015: 23-24).

Novel adalah sebuah karya tulis yang memiliki unsur-unsur intrinsik dan ekstrinsik berbentuk prosa atau bisa disebut juga sebagai sebuah karya tulis yang merupakan penggambaran kisah atau cerita yang diaplikasikan dalam bentuk sastra atau kata-kata yang memiliki unsur - unsur intrinsik dan ekstrinsik yang meliputi tema, penokohan, alur, gaya bahasa, latar / setting, sudut pandang, dan juga terdapat amanat (Stilistika, 2009:6). Lewat sudut gaya bahasa dalam novel ini, komunikasi massa menjadi sarana pelengkap untuk menjelaskan cara penyampaian bahasa Ayu yang dituangkan kedalam tulisannya di buku Anatomi Rasa agar dapat dipahami pembaca menjadi perhatian utama penulis.

Komunikasi massa merupakan komunikasi dalam penyebaran informasi melalui media massa (media cetak dan elektronik), pemanfaatan pemahaman ini yang penulis gunakan dalam menafsirkan makna massa ke penyebutan lain dari pembaca, sedangkan komunikasi yang dilakukan oleh Ayu melalui media teknologi komunikasi yaitu, novel yang merupakan tulisan atau teks. Sesuai artinya komunikasi massa yang disebarkan lewat media massa memiliki banyak jenis, diantaranya adalah televisi, radio, internet, majalah, koran, tabloid, buku, dan film (film bioskop bukan film negatif yang dihasilkan kamera) (Nurudin, 2007: 5).

Buku yang berangkat dari sebuah teks kesastraan sering mengemukakan sesuatu secara implisit sehingga hal itu boleh jadi "menyibukkan" pembaca, dan pembaca haruslah mengisi sendiri "bagian - bagian yang kosong" tersebut (ingat: peran pembaca implisit 'implicit reader'), untuk merekrontruksi cerita (Luxemberg, 1989:6). Rekrontruksi dari seorang penulis sangat berpengaruh dalam menentukan pemahaman yang akan sampai ke pembaca. Anatomi Rasa menjadi salah satu pembentuk pemikiran seseorang lewat pemaknaan kata 'kebathinan jawa' oleh sang penulis lewat media massa buku dengan jenis novel serius.

Pada dasarnya istilah kebathinan sebagai penyambung dari rasa yang merupakan kiasan dari kata kepercayaan, kepercayaan tak terlihat namun dapat dirasakan lewat pijarannya. Sematan 'urip iku urub' (hidup harus bersinar) menjadi bukti adanya daya hidup yang memancar dari diri kita sebagai mahluk hidup. Sehingga semayan kepercayaan inilah yang akan digali lebih dalam untuk mengupas isi dalam buku anatomi rasa sendiri.

Kepercayaan atau spiritulalitas menjadi cara lain seseorang memahami spiritualisme dirinya dengan menggunakan kemajuan teknologi komunikasi, yang membantu peran komunikasi dalam pemanfaatannya yaitu novel. Novel berperan sebagai media 
komunikasi yang sangat berpengaruh bahkan ampuh dalam menyampaikan pesan kepada masyarakat. Pesan yang disajikan dibuat halus dan menyentuh hati tanpa merasa digurui (Jakob, 2004:24).

Dengan penggunakan objek utama yaitu teks tentang kebathinan jawa dimana menggunakan banyak penelitian terdahulu sebagai referensi mengantarkan peneliti untuk meneliti novel Anatomi Rasa menggunakan analisis wacana Laclau dan Mouffe ditinjau dari penerapan pada subjek-objek dan khalayak atau pembaca dalam melihat wacana mengenai pemaknaan kepercayaan yang di tuliskan pada novel Anatomi Rasa. Analisis wacana Laclau dan Mouffe sangat kental dengan perspektifnya karena memfokuskan pada 3 konsep utama : titik nodal, medan kewacanaan, dan pengakhiran pada suatu wacana (Jorgensen, 2010:48).

Analisis wacana Laclau dan Mouffe pernah digunakan pada acuan utama pada penelitian pada skripsi Linn Engval yang berjudul "Women Empowerment : A discourse analysis of women's empowerment concept within UN Women" dengan menggunakan poin utama pada definisi kekuatan wanita menggunakan analisis wacana Laclau dan Mouffe dari sudut wacana. Namun pada bahasan teliti, analisis wacana Laclau dan Mouffe yang digunakan hanya sebatas sudut wacana untuk mencari bagaimana tulisan terbentuk sehingga dapat dipahami oleh pembaca.

Dalam novel serius ini Ayu, mengambarkan pemaknaan rasa pada suatu kebathinan yang berada di Jawa dengan sangat elok, segar dan menyenangkan untuk dipahami oleh pembaca. Selain dengan menyuguhkan beberapa cerita pendek sebagai pengambaran nya, pemaknaan kata rasa sendiri mengalami banyak alur dalam penjelasannya. Lewat ketertarikan isi dari pada buku ini juga perjalanan Ayu dalam dunia tulis menulis yang memiliki gaya tersendiri membuat penulis menangkat novel serius ke-tujuh Ayu sebagai bahan penelitian dengan judul "ANALISIS WACANA TENTANG KEBATHINAN JAWA DALAM NOVEL ANATOMI RASA KARYA AYU UTAMI".

\section{KAJIAN LITERATUR}

\subsection{Tinjauan Pustaka}

\subsubsection{Komunikasi Massa}

Komunikasi massa adalah sebuah proses komunikasi yang diarahkan kepada khalayak yang sangat luas, disalurkan melalui srana audio dan/atau visual.komunikasi massa berlagsung dlama suatu konteks sosial. Media mempengaruhi konteks sosial dan sebaliknya. Dengan kata lain, terjadi hubungan transksaksional antara media dan masyarakat (Devito, 1997).

Singkatnya komunikasi massa adalah proses banyak menerima pesan namun tidak perlu tatap muka untuk mengirim pesan kepada audien yang luas dengan tujuan memberi informasi, menghibur, atau membujuk. Komunikasi massa juga berpengaruh dalam tahap menyebarkan suatu pesan hingga dapat dipahami oleh kahalayak luas atau pembaca dalam kasus ini.

\subsubsection{Buku}

Seperti yang dijelaskan oleh Lazarsfeld dan Merton(1951) dalam buku Mass Comunication, popular taste, and organized social action mengatakan :

"Orang yang membaca banyak pokok permasalahan dan bahkan mungkin mendiskusikan alternatif - alternatif tindakan. Tetapi ini lebih merupakan proses intelektual yang tidak mengaktifkan tindakan sosial. Warga masyarakat yang berkepentingan dan mengetahui informasi ini dapat memberi selamat kepada dirinya sendiri atas informasi yang diperolehnya dan lupa menyadari bahwa ia tidak dilibatkan dalam keputusan dan tindakan. Ia mengkelirukan antara mengetahui persoalan dan melakukan sesuatu atas persoalan tersebut".

\section{GAMBAR 2.1}

Hubungan Pengarang dengan Pembaca dalam Penyampaian Amanat secara Tidak Langsung 


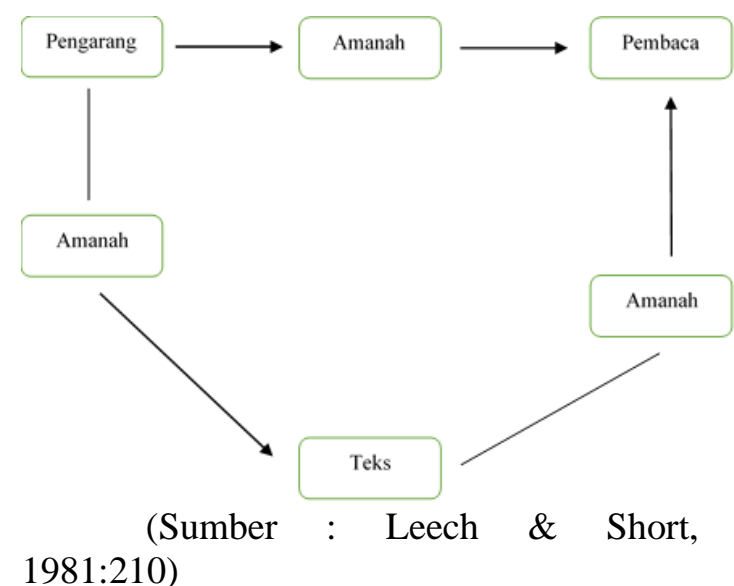

Dari gambar 2.1 diatas menjelaskan proses komunikasi seorang pengarang dalam menuangkan pengetahuannya tentang suatu informasi, yakni membahas tentang kebathian Jawa. Yang disampaikan melalui amanah dan dituangkan dalam bentuk tulisan ke dalam novel yang ditulisnya, Anatomi Rasa. Setelahnya tulisan tersebut dapat di nikmati oleh para pembaca lewat bagaimana pembaca dapat memahami amanah yang disampaikan oleh pengarang tentang kebathinan Jawa yang luas pemaknaannya.

Singkatnya penelitian ini ialah proses pengarang dalam menyampaikan amanah atau pemahamannya tentang kebathinan Jawa melalui teks tulisan berbentuk buku dengan jenis novel sehingga dapat dimengerti oleh para pembacanya.

\subsubsection{Novel}

Novel - novel besar biasanya tidak menonjolkan pesan dan moral yang ingin disampaikan kepada pembaca betapapun "penting"-nya pesan itu menurutnya. Atau, mungkin yang terjadi sebaliknya, karena tidak menggurui pembaca, novel - novel itu menjadi besar. Besar da;am arti bernilai literer tinggi, banyak dibaca dan dikagumi pembaca, dan bertahan dari waktu ke waktu. Karena mengungkap berbagai sisi kemanusiaan yang hakiki, novel - novel itu tidak menjadi ketinggalan zaman (Nuriyanto,2015:471).

Novel memiliki unsur pembangunan novel dapat mengemukakan sesuatu secara bebas, menyajikan sesuatu secara lebih banyak, lebih rinci, lebih detil, dan lebih banyak melibatkan berbagai permasalahan yang kompleks. Dari unsur pembangunan ini dapat membentuk suatu pemahaman bagi pembaca lewat apa yang disampaikan penulis yang dikomunikasi secara tidak langsung tersebut. Di era modern ini novel banyak diadaptasi ke dalam bentuk digital, hal ini memudahkan khalayak atau pembaca dalam mempersingkat waktu untuk memilih kebutuhan bacaan yang diperlukannya. Namun demikian, perpindahan era konvesional ke digital juga memiliki dampak dalam perkembangan novel sendiri, yaitu pembajakan buku secara besar - besaran.

\subsubsection{Analisis Wacana \\ 2.1.3.1 Wacana}

Wacana adalah komunikasi lisan atau tulisan yang dilihat dari titik pandang kepercayaan, nilai, dan kategori yang masuk didalamnya; kepercayaan di sini mewakili pandangan dunia; sebuah organisasi atau representasi dari pengalaman (Roger Folwer,1977).

Wacana merupakan gagasan umum bahwa bahasa ditata menurut pola yang berbeda yang diikuti oleh ujaran para pengguna bahasa ketika mereka ambil bagian dalam domain - domain kehidupan sosial yang berbeda, misalnya dalm domain "wacana medis" dan "wacana politik". Dengan demikian "analisis wacana" merupakan analisis atas pola - pola tersebut (Jorgensen, 2010:1).

Wacana adalah suatu bahasa yang di komunikasikan secara tidak langsung dan langsung, yang dihubungkan lewat rentetan porposi yang membentuk suatu kesatuan sehingga membentuk suatu makna yang digunakan untuk mengkontruksi pesan yang akan disampaikan ke khalayak.

\subsubsection{Analisis Wacana}

Istilah "Analisis Wacana" misalnya, dalam linguistik digunakan untuk menggambarkan analisis hubungan - hubungan anatara kalimat dan penyataan pada tataran mikro (Brown dan Yule, 1983). Menurut Van Dijk 
dan Kintch (dalam Jorgansen, 2010:111) Analisis wacana juga telah digunakan untuk mengambarkan analisis terhadap cara - cara orang dalam menggunakan skema mental untuk memahami naratif.

Tujuan analisis wacana adalah memetakan proses yang berguna untuk mengetahui cara yang digunakan dalam menetapkan makna tanda - tanda dan proses dalam membuat sebagian penetapan makna sehingga dapat di konvensionalisasikan agar kita dapat menganggapnya sebagai upaya pemetaan makna secara alami (ibid.,48).

Kajian linguistik berurusan dengan aturan aturan bahasa, maka dari itu analisis wacana tertarik pada aturan - aturan transaksi pesan. Dari segi analisisinya, ciri dan sifat analisis wacana dapat dikemukakan oleh Sobur (2009:49-50) sebagai berikut :

1. Analisis wacana merupakan pemahaman tentang rangkaian tuturan melalui intrepertasi semantik.

2. Analisis wacana berkaitan dengan pemahaman bahasa dalam tindak berbahasa.

3. Analisis wacana diarahkan kepada masalah memakai bahasa secara fungsional.

4. Analisis wacana membahas kaidah memakai bahasa dalam masyarakat.

Sesuai dengan pemaparan diatas menunjukkan analisis wacana haruslah apa yang ditulis, dengan bermacam eksplorasi pola yang muncul pada lintas penyataan dan menidentifikasi konsekuensi sosial sebagai bentuk representasi kewacanaan yang berbeda atas realitasnya.

\subsubsection{Analisis wacana Laclau dan Mouffe}

Dalam jurnal Arifin (2017:3(1)) menyebutkan teori wacana Ernesto Laclau dan Chantal Mouffe berfokus pada wacana yang mengonstruk makna dalam dunia sosial karena bahasa tidak stabil dan tidak pernah permananen dan karena itu kita mesti telanjang dan benar-benar bersih. Pendekatan Teori Wacana Ernesto Laclau dan Chantal Mouffe merupakan Teori Postrukturalis yang paling "murni". Teori ini bertitik pangkal dari gagasan postrukturalis yang menyatakan bahwa wacana mengonstruk makna dalam dunia sosial dan karena secara mendasar bahasa itu tidak stabil, bahasa tidak pernah dapat tetap secara permanen. Konstruksi makna yang dapat digunakan dalam ranah bahasa memiliki peran sendiri untuk menentukan hasil yang disampaikan ke khalayak ramai, sehingga hal ini yang mendasari peneliti menggunakan teori wacana Laclau dan Mouffe dalam meneliti novel Anatomi Rasa.

Dalam uraiannya Laclau dan Mouffe menetapkan tiga konsep utama dalam teorinya, yakni : 'titik nodal' (Chain of Equivalence) (titik - titik tanda persetujuan), 'medan kewacanaan' (field of discursivity) dan 'pengakhiran' (closure).

\subsubsection{Titik Nodal}

Suatu wacana dibentuk dengan penetapan makna disekitar titik nodal. Titik nodal merupakan suatu tanda yang mempunyai hak khusus yang tempat disekitarnya bisa digunakan untuk menata tanda - tanda lain. Tanda - tanda lain tersebut memperoleh makna dari hubungannya dengan titik nodal tersebut. Titik nodal pada penelitian ini juga berbentuk Chain of equivalence, agar sebelum memasuki ke tahap selanjutnya dapat menentukan poin - poin yang akan di bahas dalam medan kewacanaan.

\subsubsection{Medan Kewacanaan}

Semua kemungkinan yang ditiadakan disebut dengan medan kewacanaan, ialah cadangan bagi 'surplus makna' yang dihasilkan oleh praktik artikulatoris, yaitu makna - makna yang dimiliki atau telah dimiliki oleh setiap tanda dalam wacana wacana lain namun yang ditiadakan oleh wacana khusus guna menciptakan kesatuan makna.

\subsubsection{Pengakhiran}

Wacana pengakhiran, sebutan lain dari penghentian sementara pada fluktuasi fluktuasi yang terdapat pada makna tanda tanda. Namun pengakhiran itu sendiri tidak pernah pasti dikarenakan wacana berusaha mentransformasikan unsur - unsur ke dalam momen atau medan kewacanaan dengan cara mengurangi poliseminya 
(makna ganda) hingga menjadi makna yang sepenuhnya tetap.

\subsubsection{Penerapan Analisis Wacana pada Novel}

Menurut Jorgensen dan Philips pada tesis Linn Engvall, menjelaskan bahwa teori analisis Laclau dan Mouffe sebenarnya termasuk sulit untuk di pakai, kembali pada tujuan awaldari penelitian mereka ialah untuk membantu pengembangan teori dan tidak menyediakan alat konkret untuk di analisis. Namun Engvall percaya bahwasannya teori analisis mereka cocok untuk menganalisis tesis laporannya dengan menggunakan sesuai konsep yang telah dijelaskan oleh Laclau dna Mouffe.

Kunci dari penerapan analisis wacana pada penelitian ini dengan menggunakan tiga macam konsep dari Laclau dan Mouffe dengan menerapkan dua teori analisis yang akan menjadi poin utama yakni, Chain of equivalence (rantai kesetaraan) dan titik nodal. Chain of equivalence berfungsi sebagai penghubung antara tanda - tanda yang menjadi pembentuk suatu makna dalam analisis penelitian pada novel. Sedangkan titik nodal berfungsi menjelaskan makna keseluruhan dari suatu teks yang ada pada novel, hal ini berguna sebagai tujuan awal dari penelitian, menemukan maksud dari pengarang dalam menyampaikan pendapat dan pesan lewat novel yang dituliskan, sedangkan pembaca menemukan apa isi dari novel dengan tana mengurangi rasa kekeliruan dalam memahami teks yang dibaca.

Berangkat dari penyampaian penulis tentang teks kebathinan jawa, dengan menggunakan Chains of equivalence dan titik nodal, peneliti akan menentukan rantai - rantai penting dalam teks tentang kebathinan jawa, lalu menemukan satu makna penting yang dapat diterima oleh pembaca agar mengurangi rasa kesalah pahaman dalam membaca suatu informasi pemaparan dari teks tentang kebathinan jawa lewat novel Anatomi Rasa melalui argumentasi dari peneliti.

\section{METODE PENELITIAN}

\section{1 Paradigma Penelitian}

Menurut Aridanto dan Q-Anees (2007:81) menjelaskan ada lima paradigma dalam suatu penelitian yaitu, positivism, postpositivsm, interpretif, konstruktivism, dan kritis. Dalam penelitian ini, peneliti memilih konstruktivis sebagai paradigma yang paling sesuai dikarenakan paradigma konstruktivis menganggap subjek sebagai faktor sentral dalam kegiatan komunikasi serta hubungan - hubungan sosial hal ini didasari dengan realitas dikonstruksi oleh masyarakat dan praktisi dalam hal ini ialah pembaca dan penulis, pemberian makna dan pemahaman maknalah yang mengkonstruksi suatu realitas.

Penelitian memiliki tujuan yaitu bersifat penemuan, pembuktian dan pengembangan. Penemuan berarti data atau fakta terbaru yang dikumpulkan melalui uji validitas dari data yang belum pernah diketahui sebelumnya. Pembuktian berarti data yang diperoleh benar adanya tanpa keragu raguan terhadap suatu informasi yang dipaparkan atau pengetahuan tertentu, dan pengembangan berarti pendalaman dan perluasan pengetahuan yang telah ada. Maka dari itu diharapkan dengan adanya penelitian ini dapat membuktikan pemahaman dan pengalaman peneliti sebagai pembaca dan dapat disebarkan kepada khalayak pembaca lain agar tidak memiliki kesalahan dalam pengartian tentang teks kebathinan jawa yang ada dalam buku Anatomi Rasa karya Ayu Utami.

\section{2 Metode Penelitian}

Pendekatan penelitian yang digunakan adalah pendekatan kualitatif. Metode kualitatif merupakan meneliti manusia serta dunia sosial. Dalam buku Sugiyono dapat disimpulkan bahwa metode kualitatif dinilai sangat cocok dalam penelitian untuk menemukan suatu hipotesis/teori.

Penelitian ini menggunakan metode analisis wacana dari Laclau dan Mouffe, alasan peneliti menggunakan teori ini didasari dengan adanya kesinambungan antara objek yang di teliti dengan teori yang bersangkutan. 
Dalam penelitian ini membahas teks kebathinan Jawa sebagai objek, bagaimana cara penulis dari Ayu Utami memaparkan atau menuangkan pemikiran tentang teks kebathinan jawa dalam novel tertulis, didasari teori analisis wacana dalam menyatukan rantai - rantai dari tiap kata yang menjelaskan teks kebathinan Jawa dan argumentasi peneliti dalam menangkap maksud yang disampaikan oleh Ayu Utami dalam tulisannya.

\section{3 Objek Penelitian}

Objek yang digunakan dalam penelitian ini adalah teks dari novel Anatomi Rasa karya Ayu Utami yang mengandung unsur tentang kebathinan Jawa.

\section{4 Unit Analisis Penelitian}

Dibawah ini merupakan satu kasus sebagai contoh bagaimana peneliti akan membahas tiap tiap hal yang berhubungan dengan kebathinan Jawa dalam buku novel Anatomi Rasa karya Ayu Utami.

"Tapi, di kalangan pencari spiritual pun kedangkalan bukan tidak bisa terjadi. Mereka yang memburu pemuasan rasa haru magis atau rasa remang dunia gaib juga berisiko terjebak dalam kedangkalan sensasi." (5)

Titik nodal atau Chain of equivalence merupakan cara penting peneliti untuk mencari poin - poin yang berkesinambungan dengan pokok bahasan di telitian ini, mencari kesatuan dalam teks kebathinan Jawa. Berikut merupakan salah satu contoh dari cara mencari chain of equivalence pada novel Anatomi Rasa.

"Tapi, di kalangan pencari spiritual pun kedangkalan bukan tidak bisa terjadi. Mereka yang memburu pemuasan rasa haru magis atau rasa remang dunia gaib juga berisiko terjebak dalam kedangkalan sensasi." (5)

Chain of equivalence : pencari spiritual magis - rasa remang - dunia gaib kedangkalan sensasi.
Medan Kewacanaan disini berfungsi sebagai pemersatu dari tanda - tanda yang telah di sebutkan pada titik nodal sebelumnya, yakni pencarian makna lewat potongan - potongan kata yang disebut dalam sebuah parafrag dalam novel Anatomi Rasa.

Medan Kewacanaan : Melalui kata pencari makna yang dimaksud ialah untuk seseorang yang sedang mencari jati diri dan ingin menemukan apa yang ada didalam kehidupan sebagai tujuan utama dari atas segala pencariannya. Melalui magis atau rasa remang dunia gaib seseorang yang tidak diketahui identitasnya ini memilih untuk mencari jalan keluar atau solusi atas apa yang dicarinya selama ini. Namun hal ini juga bisa beralih ke hal yang buruk karena memiliki sebuah resiko yaitu sebuah kedangkalan sensasi dimana dalam kebathinan Jawa sendiri bila seseorang salah dalam memilih cara memahaminya maka akan sangat mudah dalam terjerumus ke hal yang sesat. Karena kembali pada tujuan utama dari kebathinan Jawa ialah untuk mencari ketentraman hati kepada Tuhan atau hubungan intrapersonal diri dan Tuhan sang pencipta.

Pengakhiran atau kesimpulan sebagai bentuk kesetujuan peneliti dengan apa yang ada tertulis dalam buku menjadi bagian penutup dalam unit analisis ini.

Pengakhiran : Dapat disimpulkan dari apa yang terpapar dan argumen dari penyematan di tiap - tiap kata yang disebutkan oleh Ayu, peneliti memahami bahwasannya dalam mencari pemaknaan hidup dapat dilakukan melalui banyak cara seperti melalui rasa remang magis yang sulit didefinisikan cara dan tata pengerjaannya dan terkadang sering tak masuk akal dengan efek yang dihasilkannya, namun kembali lagi kepada tujuan kebathinan Jawa, yakni mencari ketenangan jiwa dan mendekatkan diri dengan sang pencipta, maka dari itu jangan sampai rasa penasaran atau penyalahgunaan kegiatan magis membawa petaka kepada pelaku dikemudian harinya.

\subsection{Teknik Pengumpulan Data}


Pengumpulan data dilakukan untuk kebutuhan penelitian. Dalam proses perolehan data, penulis menggunakan data berikut :

\section{Data Primer}

Data primer merupakan data utama yang digunakan dalam melakukan penelitian. Dengan begitu, data primer yang digunakan untuk penelitian ini adalah setiap kalimat yang mengandung unsur Kebathinan Jawa dalam novel Anatomi Rasa.

\section{Data Sekunder}

Data ini digunakan sebagai data pendukung yang dibutuhkan oleh peneliti untuk melengkapi data primer yang dimiliki. Dalam penelitian ini, data sekunder didapatkan dengan melakukan studi pustaka. Studi pustaka yang dilakukan untuk penelitian ini adalah dengan mengumpulkan data dengan mencari buku mengenai Kebathinan Jawa, artikel mengenai penulis Ayu Utami, dan juga buku-buku lain yang menunjang penelitian ini.

\section{6 Teknik Analisis Data}

Dalam penelitian ini penulis menggunakan teknik analisis wacana dari Laclau dan Maufe dengan menggunakan tiga tahap penemuan makna dari tulisan yang ada pada objek teliti, adapun tahapan yang dilakukan oleh penulis dengan tindakan sebagai berikut:

1. Membaca buku novel Anatomi Rasa karya Ayu Utami lebih dari sekali untuk mendapat pemahaman lebih dari inti buku.

2. Mempelajari data yang bersangkutan dengan kebathinan Jawa, menandai kata kata dan gagasan sebagai poin titik nodal.

3. Mempelajari tiap kata kunci, menemukan makna dan arti yang dipahami oleh pembaca secara general sebagai bentuk dari representasi medan kewancanaan.

4. Menemukan tema - tema dari kata yang menjelaskan kebathinan Jawa secara jelas sesuai teori dan buku - buku pendukung sebagai bentuk pengakhiran.

5. Mengambil kesimpulan dari tiap kalimat yang akan digabungkan pada hasil penelitian untuk mencapai apa yang sebenarnya inti dari kebathinan Jawa yang ingin disampaikan oleh penulis.

Singkatnya peneliti akan mengumpulkan keseluruhan data yang bersinggungan dengan objek teliti dari penelitian ini. Setelahnya menentukan chain of equivalence dalam menentukan rantai rantai penyatuan dari tiap kata yang bersinggungan dengan teks kebathinan Jawa. Sehingga dapat di tentukan medan kewacanaan dari suatu paragraf atau kalimat yang diteliti. Diperlukan analisis secara tajam terhadap segala rantai penentu ditiap kata dan kalimat sehingga mendapatkan medan kewacanaan yang akurat dan kesimpulan atau pengakhiran yang hati - hati agar tidak menyebabkan kesalahan informasi kepada pembaca.

\section{7 Teknik Keabsahan Data}

Pada penelitian ini, peneliti memilih teknik ketekukan/keajegan pengamatan sebagai teknik keabsahan data pada novel Anatomi Rasa karya Ayu Utami ini. Hal ini dikarenakan teknik ini memberikan deskripsi data yang akurat dan sistematis tentang apa yang diamati oleh peneliti. Dengan cara membaca referensi - referensi buku dari kebathinan Jawa, Jurnal, artikel maupun hasil penelitian atau dokumentasi yang terkait dengan penelitian ini. Hal ini juga dikarenakan dengan membaca wawasan dari peneliti semakin meningkat, luas dan tajam, sehingga dirasa sangat cocok untuk memeriksa data yang disajikan pada bab 4 benar atau tidak.

Pada teknik ini sendiri, menurut Moleong (2018:329) menjelaskan bahwa keajegan pengamatan ialah mencari konsistensi intrepertasi yang berkaitan dengan proses analisis konstan atau tentatif. Dalam hal ini tulisan pada novel bersifat konstan hal ini didasari oleh tulisan pada novel yang menjelaskan kebathinan Jawa tidaklah dapat berubah - ubah sebab kebathinan Jawa merupakan hal yang sudah pasti pembelajarannya. Dengan begitu teknik ini juga ditujukan untuk mencari suatu batasan dari berbagai multi tafsir dari kebathinan Jawa dan mencari apa yang dapat 
diperhitungkan dan apa yang tidak dapat diperhitungkan.

\section{PEMBAHASAN}

Berdasarkan analisis yang sudah dipaparkan dalam penelitian ini, ditemukan hasil pengakhiran tiap analisis wacana pada 11 paragraf sebagai berikut:

\subsection{Tulisan pertama}

\section{Paragraf 1 pada halaman 5.}

Dapat disimpulkan dari apa yang terpapar dan argumen dari penyematan di tiap - tiap kata yang disebutkan oleh Ayu, peneliti memahami bahwasannya dalam mencari pemaknaan hidup dapat dilakukan melalui banyak cara seperti melalui rasa remang magis yang sulit didefinisikan cara dan tata pengerjaannya dan terkadang sering tak masuk akal dengan efek yang dihasilkannya, namun kembali lagi kepada tujuan kebathinan Jawa, yakni mencari ketenangan jiwa dan mendekatkan diri dengan sang pencipta, maka dari itu jangan sampai rasa penasaran atau penyalahgunaan kegiatan magis membawa petaka kepada pelaku dikemudian harinya.

\subsection{Tulisan kedua}

Paragraf 3 pada halaman 11 - 12.

Dapat disimpulkan hal ingin disampaikan oleh Ayu merupakan bahwa seseorang membutukan petunjuk untuk menemukan ketenangan dan ketentraman dari diri sendiri dengan mencari cara bagaimana suatu Rasa dapat diterapkan kedalam keseharian seseorang sebagain individu manusia.

\subsection{Tulisan ketiga}

\section{Paragraf 3 pada halaman 13.}

Simpulan yang dapat diambil dari tiga hal universal dalam menentukan pola dari cara mencari jati diri ialah dengan menentukan terlebih dahulu diri tentang keinginan apa yang mau dicari agar memudahkan diri dalam menentukan tahap pencarian diri ke tahap selanjutnya yakni langkah yang harus diambil dan salah satu caranya ialah dengan melihat kedalam diri sendiri.

\subsection{Tulisan keempat Paragraf 3 pada halaman 16.}

kesimpulan yang dapat diambil dari tulisan diatas ialah kata Rasa memiliki makna sakti bagi pemeluk dari kebathinan Jawa, hal ini dapat ditemukan pada beberapa falsafah timur yang disebutkan dalam buku ayu utami. Sedangkan peran dari spiritual ialah sebagai benang merah dari atas segala pencarian dari jati diri seseorang dalam kebahtinan Jawa ini sendiri.

\subsection{Tulisan kelima}

Paragraf 1 pada halaman 21.

Cara yang dijelaskan diatas ialah bagaimana cara mengolah Rasa secara prakteknya adalah hal yang kita sebut sekarang dengan nama meditasi. Hal ini membantu meningkatkan daya kognitif dari seseorang juga mengurangi rasa cemas dan ketidak teraturan atas segala hal yang terjadi diluar kendali dari diri kita.

\subsection{Tulisan keenam}

\section{Paragraf 1 pada halaman 22.}

Inti dari lapisan atau tingkatan ini ialah untuk menyatukan dari tiap - tiap macam Rasa, dengan menyatukan dari masing masing kegunaan utama dari Rasa itu sendiri, namun dari tiga lapisan tersebut yang menjadi bahasan utama dari penelitian ini ialah rasa rohani dimana, rasa rohani menunjukkan spiritualitas seseorang dengan sang ilahi lewat latihan kebathinan.

\subsection{Tulisan ketujuh}

\section{Paragraf 3 pada halaam 30 - 31 .}

Pada tulisan ini kepekaan rasa batin sangat berkesinambungan dengan ilmu kaweruhan, pada halnya dengan bantuan dari tulus dan ridha hati dalam melihat kedalam diri juga mencari sang ilahi membuat individu mendapatkan ilmu kaweruhan terhadap diri.

Maka dari itu keikhlasan dalam mempelajari kebathinan Jawa sangat diutamakan dalam hal ini. Semakin individu yang bersangkutan ikhlas, semakin mempermudah individu menerima kebaikan untuk dirinya.

\subsection{Tulisan kedelapan}

\section{Paragraf 2 pada halam 39.}

Simpulan yang dapat diambil pada tulisan kedelapan ini, menunjukkan bahwa integritas batin menjadi tujuan dari tingkat 
spiritualitas seseorang dalam pelajar kebathinan Jawa ini. Bila disandingkan dengan membaca novel Anatomi Rasa sendiri, pembaca dapat menemukan cara melatih dari integritas batin. Hal ini dibuktikan pada tulisan kesebelas.

\subsection{Tulisan kesembilan}

Paragraf 2 pada halamn 39.

Simpulan yang dapat diambil ialah, sebagai individu yang mencari ketenangan diri ada baiknya untuk menyeimbangkan antara pemikiran rasional dan pengetahuan spiritual, hal ini guna untuk menyelaraskan diri untuk dapat melihat suatu perkara dengan dua perpektif yang berbeda.

\subsection{Tulisan kesepuluh}

\section{Paragraf 2 pada halaman 85.}

Pada bagian ini menunjukkan tahap dimana seseorang telah menerima ketenangan dan ketentraman lewat perjalanan spiritualnya, kebathinan Jawa sendiri sebenarnya sangat membuka perpektif diri dengan lebih melihat kedalam batin diri kita sendiri sehingga menghasilkan daya hidup yang memancar, masyarakat kini menyebutnya inner beauty. Setelah menuntaskan ketentraman diri hal itu pula yang disebut dengan Manunggaling kawula gusti.

\subsection{Tulisan kesebelas}

\section{Paragraf 2 pada halaman 95.}

Dengan melakukan latihan batin ini, membuka pikiran dan hati menjadi lebih ringan dan bersih. Batin menjadi tentram dan bahagia secara tulus. Hal ini sangat mempengaruhi individu yang memang mencari ketentraman sebagai tujuan utama dari kebathinan Jawa ini sendiri. Singkatnya, hal yang dapat diambil dari segala pelajaran pada tulisan kesebelas ini ialah kebathinan Jawa yang diangkat oleh sang penulis adalah kebathinan Jawa yang mengarah pada pencarian ketentraman jiwa dan hari.

\section{PENUTUP}

\section{1 Kesimpulan}

Dari kesebelas tulisan, menunjukkan kebathinan Jawa yang disampaikan oleh penulis adalah sebagai penemuan ketenangan diri, pendekatan diri dengan sang pencipta juga cara untuk mengelola jiwa dalam menanggulangi segala permasalahan dikehidupan sehari - hari. Selain dari cara mengelola terdapat satu cara dalam menanggulangi resah, gundah, atau ketidak tentuan hati dengan melakukan kegiatan meditasi dengan aturan cara yang terdapat pada paragraf 11 yang menjelaskan runtut satu persatu cara untuk melakukan meditasi.

\subsection{Saran}

Bagi peneliti selanjutnya, penelitian ini masih terdapat kekurangan. Salah satunya ialah bagaimana peneliti menyajikan data dan hasil pemikirannya secara general dalam penelitian. Maka diharapkan pada peneliti yang menggunakan objek atau konteks yang sama untuk lebih memperluas wawasan dengan yang diteliti. Selain itu kajian penelitian tentang analisis novel menggunakan metode analisis wacana Laclau dan Mouffe agar penelitiannya lebih spesifik dan rinci untuk menambah referensi mahasiswa/i yang sedang menyusun tugas akhir atau skripsi yang bertemakan buku novel.

Bagi penulis, diharapkan lebih menjelaskan hal yang berkaitan dengan sosial, budaya, serta kepercayaan yang berlaku dengan menggunakan bahasa yang lebih mudah dipahami oleh pembaca yang tidak mengerti spiritual kritis agar pembaca mendapatkan maksud dari kepercayaan lokal secara benar dan mudah dipahami.

\section{REFERENSI}

Ardianto, \& Q-Anees. (2007). filsafat ilmu komunikasi. Bandung: Simbiosa Rekatama Media.

Devito, J. A. (1997). Komunikasi Antarmanusia : Edisi Kelima. Jakarta: Professional Books.

Jorgensen, M. W., \& Phillips, L. J. (2010). Analisis Wacana Teori dan Metode : Cetakan Kelima. Yogyakarta: Pustaka Pelajar.

Lazarsfeld, P. F., \& K., M. R. (1951). Mass Communication, Popular Taste, and Organized Social Action. New York: Harper \& Row. 
Leech, G., \& Short, M. (2007). Stile in Fiction, a Linguistic Introduction to English Fictional Prose. London: Longman.

Luxemburg, J. V., Bal, M., \& Westeijn, W. G. (1989). Tentang Sastra (Terjemahan Akhadiati Ikram). Jakarta: Intermasa.

Nurgiyantoro, B. (2015). Teori Pengkajian Fiksi : Cetakan Kesebelas. Yogyakarta: Gadjah Mada University Press.

Nurudin. (2007). Pengantar Komunikasi Massa : Cetaka Keenam. Jakarta: Rajawali Pers.

Prof. Dr. Lexy J. Moleong, M. (2018). Metodologi Penelitian Kualitatif. Bandung: Rosda.

Sobur, A. (2009). Analisis Teks Media : Suatu Pengantar untuk Analisis Wacana, Analisis Semiotik, dan Analisis Framing.

Bandung: Remaja Rosdakarya.
Sugiyono, P. D. (2017). Metode Penelitian Kuantitatif, Kualitatif, dan $R \& D$. Bandung: Penerbit Alfabeta.

Utami, A. (2019). Anatomi Rasa. Jakarta: Kepustakaan Populer Gramedia.

\section{BIODATA PENULIS}

Cut Dalillah Sofa. Fakultas Komunikasi dan Bisnis. Universitas Telkom, Indonesia. Email: cutdalillah@gmail.com.

Lucy Pujasari Supratman. Fakultas Komunikasi dan Bisnis. Universitas Telkom, Indonesia. Email : doktorlucysupratman@gmail.com 